\title{
HUBUNGAN AUSTRALIA-INDONESIA DI MASA PEMERINTAHAN PRESIDEN SUSILO BAMBANG YUDHOYONO (SBY)
}

\author{
Sherin Megananda, Badrus Sholeh \\ Program Studi Ilmu Hubungan Internasional, Universitas Islam Negeri Syarif Hidayatullah Jakarta \\ Program Studi Ilmu Hubungan Internasional, Universitas Islam Negeri Syarif Hidayatullah Jakarta
}

Sherinmegananda@mhs.uinjkt.ac.id, Badrus.sholeh@uinjkt.ac.id

\begin{abstract}
Abstrak
Hubungan bilateral antara Australia dan Indonesia selalu dinamik. Pada penelitian ini, berfokus kepada kebijakan-kebijakan Presiden SBY terhadap Australia yang kemudian menandai bagaimana naik turunnya hubungan bilateral kedua negara tersebut. Pemilihan topik ini didasarkan atas keingin tahuan penulis tentang hubungan antara Australia dan Indonesia yang membingungkan karena pada sejarahnya hubungan ini selalu disebut dengan "Roller Coaster Relationship". Namun pada penelitian ini, penulis memfokuskan pembahasan pada masa kepemimpinan Presiden SBY. Metode yang digunakan berupa penelitian Kualitatif dengan menggunakan data-data sebagai acuan. Hubungan Australia dan Indonesia pada sejarahnya selalu naik turun, tidak terkecuali saat masa pemerintahan SBY, hal ini dikarenakan pergantian kepemimpinan di Australia, perbedaan-perbedaan antara Australia dan Indonesia, meskipun begitu faktor geografi mengharuskan kedua negara dapat saling beradaptasi satu sama lain. Penelitian ini diharapkan dapat menjadi referensi hubungan Australia-Indonesia bagi peneliti lainnya dimasa depan.
\end{abstract}

Kata Kunci : Demokrasi, Hubungan Australia-Indonesia, Presiden Indonesia Susilo Bambang Yudhoyono.

\begin{abstract}
Bilateral relations between Australia and Indonesia are always dynamic. In this study, it focuses on President SBY's policies towards Australia which then marks how ups and downs of bilateral relations between the two countries. The choice of this topic is based on the writer's curiosity about the relationship between Australia and Indonesia which is confusing because historically this relationship has always been called the "Roller Coaster Relationship". But in this study, the author focuses the discussion on the leadership period of President SBY. The method used in the form of qualitative research using data as a reference. Australia and Indonesia relations have historically fluctuated, including during SBY's reign, this is due to the change of leadership in Australia, differences between Australia and Indonesia, even though geographic factors require the two countries to adapt to each other. This research is expected to be a reference for Australia-Indonesia relations for other researchers in the future.
\end{abstract}

Keyword : Australia-Indonesia Relationship, Democracy, Presiden of Indonesia, Susilo Bambang Yudhoyono. 


\section{Pendahuluan}

\subsection{Latar Belakang}

Hubungan internasional antar negara bisa terjadi dalam berbagai cakupan seperi hubungan bilateral, hubungan antar regional, maupun hubungan multilateral. Hubungan antar Negara ini didasarkan pada sifat negara yang tidak jauh dari sifat manusia yang mana sejatinya adalah makhluk sosial dan tentu memerlukan bantuan dari makhluk lain, makhluk lain tersebut dapat diartikan sebagai negara lain yang akan membantu untuk memenuhi kepentingan nasional masing-masing negara yang dalam hal ini bisa dilakukan dengan cara diplomasi dan kerjasama. Hubungan yang terjadi jika 2 negara saling berinteraksi untuk memenuhi sasaran dan tujuan politik luar negerinya biasa diketahui sebagai hubungan bilateral. Namun sama halnya dengan hubungan antar manusia yang dinamis, hubungan bilateral suatu negara pun dapat kapan saja mengalami keadaan pasang surut bahkan pemutusan yang diakibatkan oleh berbagai faktor dan apabila hubungan bilateral tersebut tidak ditangani secara baik maka akan sangat berpengaruh terhadap keberlangsungan bilateral antar negara tersebut (Irsan, 2010). Terlebih lagi jika hubungan bilateral ini di lakukan oleh dua Negara yang saling berdekatan secara geografis, karena akan sangat memungkinkan untuk terjadinya hal-hal seperti mencampuri urusan dalam negeri, spionase, penurunan kepercayaan, dan hal memungkinkan lain yang menyangkut keamanan bersama kedua negara. (Shoelhi, 2011).

Dinamika hubungan bilateral antara Australia dan Indonesia sebagai Negara yang saling bertetangga dapat disebut sebagai suatu hubungan yang sangat unik dan jarang terjadi, hal tersebut dikarenakan selalu ada fase dimana hubungan tersebut mengalami kenaikan namun pada saat yang lain akan mengalami penurunan, sehingga tidak jarang penulis-penulis lain yang menyebut hubungan bilateral antara Australia dan Indonesia dengan sebutan "The Roller Coaster" dalam tulisannya. Jika dilihat secara geografis, Australia dan Indonesia merupakan negara yang saling bertetangga sehingga hubungan antara keduanya tentu diwarnai dengan banyaknya peluang kerjasama yang sangat baik, namun 
disisi lain terdapat pula tantangan yang harus dihadapi karena terlalu kompleksnya persoalan yang diakibatkan oleh banyaknya perbedaan. Hal ini sama seperti yang dipaparkan oleh Perdana Menteri Australia, Gareth Evans bahwa "tidak ada dua negara tetangga di dunia yang berbeda secara komprehensif seperti Australia dan Indonesia. Kami berbeda bahasa, budaya, agama, etnis, populasi dan berbeda dalam sistem politik, hukum serta sosial (Singh, 2002)." serta masih menyimpan kecurigaan dan trust issue antara satu dengan lainnya. Kemudian, dapat disimpulkan bahwa Australia dan Indonesia merupakan dua negara yang telihat secara kasat mata sangat amat berbeda, namun keduanya harus tetap menjaga hubungan itu demi menjaga kerjasama \& keamanan bersama mengingat Australia dan Indonesia adalah negara yang secara letak geografisnya sangat berdekatan.

Pada masa kepemimpinan Presiden SBY, mulai memberikan tanda kemunculan sistem kepemimpinan demokrasi di Indonesia yang kemudian telah memberi manfaat bagi Indonesia, hal itu juga memberikan kepercayaan diri kepada Indonesia untuk terlibat dengan komunitas internasional termasuk juga Australia karena mereka berbagi nilai-nilai demokrasi. Selain itu, artikel ini juga akan lebih berfokus kepada pandangan Indonesia sebagai negara yang dipimpin seorang Presiden dengan memiliki pandangan "Thousand friends, zero enemy", namun juga tidak akan sepenuhnya melupakan pandangan-pandangan Australia. Untuk memulai pembahasan, pandangan umum mengenai pendekatan teoritis akan dipaparkan diawal guna untuk mengetahui dasar dari hubungan Australia dan Indonesia. Beberapa kasus yang menandai "up and down" nya hubungan bilateral Australia dan Indonesia juga menjadi pembahasan yang penting karena dari hal itu kemudian akan bisa disimpulkan bagaimana hubungan bilateral antara Australia dan Indonesia pada masa kepemimpinan Presiden Susilo Bambang Yudhoyono (SBY).

\subsection{Rumusan Masalah}

Rumusan masalah pada artikel ini berupa : 
"Bagaimana hubungan bilateral antara Australia-Indonesia pada masa kepemimpinan Presiden SBY ?".

\section{Kerangka Berfikir}

Meskipun hanya menyangkut dua negara, hubungan bilateral dapat menjadi sangat kompleks sehingga penting bagi keduanya untuk memiliki kemampuan beradaptasi yang baik sehingga dapat menciptakan hubungan bilateral yang harmonis. Hubungan antara Australia dan Indonesia, dapat digambarkan sebagai "Strange Neighbours" atau tetangga yang aneh (Ball, D., \& Wilson, 1991). Deskripsi tersebut merupakan analogi yang tepat karena meskipun di satu sisi hubungan bilateral ini terancam karena adanya kerikil-kerikil tajam, namun disisi lain hubungan bilateral ini dapat menjadi simbiosis mutualisme layaknya lebah dan bunga, karena kehadiranya akan saling menguntungkan. Adanya kerangka berfikir seperti teori, konsep maupun pendekatan lain dalam sebuah penulisan, tentu akan mempermudah pembaca maupun penulis dalam memahami tema yang di bahas dalam penulisan. Adapun kerangka berfikir yang digunakan penulis sebagai berikut:

\section{Pendekatan Geografis}

Jika dihitung dari pusat geografis masing-masing negara, Australia dan Indonesia hanya berjarak $3.457 \mathrm{~km}$, selain itu Indonesia merupakan negara yang sangat penting bagi Australia jika melihat dari garis pertahanan Australia di Utara, yang mana berhadapan langsung dengan Indonesia. Hal-hal tersebut menandakan bahwa keduanya merupakan negara yang saling berdekatan secara geografis. Meskipun begitu, kedua negara ini seperti menunjukan mereka tidak cukup 'mengenal' satu sama lain yang menumbuhkan rasa saling meragu sehingga tingkat kepercayaan antar kedua negara semakin menurun dan akhirnya menimbulkan destabilisasi hubungan bilateral ini. Dilihat dari sejarah Australia, dapat diketahui bahwa Australia merupakan negara yang bukan berasal dari Eropa maupun Asia, hal ini membuat rasa tidak aman dan rasa khawatir akan jati diri Australia semakin tinggi. Rasa-rasa ketakutan seperti ini pada suatu waktu tertentu dapat menjadi tidak rasional, membahayakan, dan dapat menciptakan kecemasan antara pemimpin pemerintah dan juga di antara bagian-bagian 
masyarakat. Ini juga adalah tema yang dibicarakan berulang kali terlebih pada saat hubungan bilateral kedua negara mencapai titik terendah, melalui pendekatan Burke (Burke, 2008) dalam melihat ketakutan terhadap 'orang lain' yang ada dalam benak orang Australia ketika harus terlibat dengan Asia.

\section{Realisme}

Dilema tersebut juga bisa dilihat dengan kacamata Realis yang lahir dari pemikiran filsuf ternama seperti Machiavelli, Thucydides, dan Thomas Hobbes. Realisme berasumsi dasar bahwa sifat negara sama dengan sifat manusia yang buruk, serakah, dan egois dalam realis, negara dianggap sebagai posisi tertinggi dalam sistem yang menggunakan power sebagai alat untuk mencapai kepentingannya sehingga kemudian inilah yang disebut anarchy dalam dunia internasional. Dalam buku Leviathan, karangan salah satu filsuf realis, Thomas Hobbes. Manusia digambarkan sebagai Homo homini lupus atau serigala bagi serigala lainnya. Penjelasan dari hal tersebut adalah manusia digambarkan seperti serigala yang dalam memenuhi kepentingannya akan menumpahkan darah serigala lainnya. Namun, disisi lain manusia juga menyadari bahwa manusia takut akan hal itu, maka dari itu, manusia ini akan berkontrak sosial demi terbentuknya pengatur sosial yang saat ini adalah negara yang dalam karya Thomas Hobbes disebut sebagai sebuah leviathan atau raksasa.

Dalam topik ini, meskipun Australia dan Indonesia seperti koin yang memiliki dua sisi yang berbeda, namun keduanya juga sadar akan posisi dan kondisi yang mana mengharuskan keduanya untuk tetap saling menjaga keharmonisan hubungan bilateralnya demi mencapai keamanan bersama dan terpenuhinya kepentingan nasional masing-masing negara. Dengan begitu perlu sekali menumbuhkan serta menanamkan rasa saling percaya. Menanamkan rasa saling percaya antara dua negara tentu bukanlah suatu hal instant yang dapat diciptakan dalam waktu singkat, melainkan perlu waktu dalam periode yang lama dan perlu adanya kekonsistenan. Menurut (Booth \& Wheeler, 2007), pengembangan kepercayaan yang mengikat kurang lebih membutuhkan 2 syarat utama yaitu : 
1) kedua pemimpin sama-sama mampu melakukan sensibilitas dilema keamanan yang terdiri dari niat kapasitas aktor untuk memahami suatu motif, menunjukan respon, terhadap potensi niat militer negara lain. Atau dengan kata lain adalah bagaimana kemampuan aktor dalam menyadari bahwa mereka sedang dalam keadaan "security dilemma" dan berempati terhadap rasa takut dari aktor lain.

2) memperoleh indeks kepercayaan selama interaksi tatap muka, indeks kepercayaan adalah sinyal kredibilitas yang melekat mengenai kepercayaan orang lain yang dapat diperoleh dari pengamatan dan interaksi dengan aktor lain selama pertemuan tatap muka(Wheeler, 2018).

Hubungan Roller Coaster Australia-Indonesia tentu menunjukan tidak adanya rasa saling percaya yang tertanam, dan terus mengalami gesekan diplomatik. Pada pemerintahan SBY, sering menunjukan arah hubungan bilateral Australia-Indonesia akan semakin membaik meskipun tidak semua pergesekan tersebut hilang pada saat PM Australia yang saat itu dijabat oleh kevin Rudd dan SBY sering bertemu tatap muka.

\section{Kajian Pustaka}

Penelitian akan berfokus pada masa pemerintahan Susilo Bambang Yudhoyono. Sebagai acuan, penulis menggunakan buku berjudul "Hubungan Indonesia-Australia: Tantangan dan Kesempatan dalam Hubungan Politik Bilateral"(Chauvel \& Dkk, 2005). Buku ini membahas tentang isu-isu bilateral antara Australia dengan Indonesia yang terjadi sejak masa lampau, mulai dari krisis timor leste pada tahun 1999, isu asylum seekers, kejahatan transnasional yang mengancam keamanan bersama, dll. Selain itu, buku ini juga menjelaskan polemik perpolitikan yang terjadi pada saat pemerintahan Perdana Menteri Australia Paul Keating, John Howard dan Presiden Indonesia Soeharto, BJ Habibie dan juga Kerjasama-kerjasama antara Australia dan Indonesia seperti AMS.

Selain itu, skripsi HUBUNGAN BILATERAL INDONESIA-AUSTRALIA PADA MASA PERDANA MENTERI KEVIN RUDD (2007-2013) oleh Dwi Ana 
Wiyatiningrum juga menjadi salah satu bahan acuan, mengingat masa pemerintahan PM Kevin Rudd juga bersamaan dengan masa pemerintahan Presiden Susilo Bambang Yudhoyono sehingga skripsi ini akan menjadi pembanding yang sangat baik terhadap penelitian ini. Skripsi tersebut, mengawali penelitian dengan membahas mengenai kondisi politik maupun geografis Australia, membahas mengenai partaipartai yang sangat berpengaruh terhadap hubungan bilateral Australia-Indonesia, sejarah lengsernya John Howard dan terpilihnya Kevin Rudd sebagai Perdana Menteri, program apa saja yang akan dilakukan oleh PM Kevin Rudd, serta perubahan-perubahan yang terjadi dalam bilateral dengan Indonesia semenjak masa pemerintahannya. Pada bagian pendekatan penelitian, Skripsi ini menggunakan teori Hubungan Internasional seperti Realisme untuk menjelaskan mengenai hubungan kedua negara, pada skripsi ini juga menyetujui jika faktor geografis antara Australia Indonesia perlu di perhatikan demi terciptanya keamanan bersama.

Dalam jurnal artikel berjudul "Indonesia-Australia: Menguji Persahabatan di Tengah Konflik Penyadapan”oleh R. Aj. Rizka F. Prabaningtyas,S. IP (Prabaningtyas, 2013). Pada jurnal tersebut, penulis memberikan beberapa hal yang menurutnya sangat menarik untuk dibahas saat meningkatnya konflik antar kedua Negara ini. Mulai dari akar permasalahan yang tetap sama yaitu rasa tersinggung satu sama lain, pengambilan kebijakan berupa penarikan Duta Besar Indonesia untuk Australia, Australia yang tidak berkenan untuk meminta maaf meskipun telah melakukan penyadapan terhadap pejabat tinggi Indonesia dengan alasan mereka mengambil langkah tersebut untuk melindungi negaranya pada masa yang akan datang, namun dibalik semua ketegangan itu, keduanya sama-sama tetap ingin mempertahankan hubungan bilateral karena mengingat posisi geografis yang mengharuskan keduanya saling berkompromi salah satunya dengan melakukan faktor non-politis untuk meredam panasnya konflik seperti melakukan kerjasama dalam bidang pendidikan, kebudayaan, ekonomi,dan Investasi. Jurnal ini sama sama membahas mengenai penyadapan yang dilakukan oleh Australia terhadap Indonesia meskipun tidak menjelaskan secara rinci mengenai bagaimana penyadapan itu terjadi akan tetapi lebih kepada hal-hal yang terjadi ditengah-tengah kasus penyadapan ini.

\section{Metode Penelitian}


Metode penelitian yang digunakan dalam membuat jurnal ini adalah metode kualitatif. metode kualitatif yaitu penelitan yang dilakukan dengan cara mengumpulkan data yang mana berhubungan dengan tema dari jurnal ini yaitu HUBUNGAN AUSTRALIA-INDONESIA DI MASA PEMERINTAHAN PRESIDEN SUSILO BAMBANG YUDHOYONO (SBY). Menurut Moleong 2007 (Moleong, 2007) "Metode penelitian kualitatif adalah penelitian yang bertujuan untuk memahami fenomena apa yang dialami subjek penelitian (seperti perilaku, tindakan, persepsi, motivasi, dan lain-lain), secara holistik, dengan cara mendeskripsikan dalam bentuk kata-kata dan bahasa, pada suatu konteks khusus yang alamiah dan dengan berbagai metode alamiah".

Sedangkan menurut Creswell seorang Multimethodology,

"Qualitative research is an process of understanding based on distinct methodological traditions of inquiry that explore a socialor human problem. The researcher builds a complex, holistic picture, analize word, report detailed views of information, and conducts the study in a natural setting"

atau penelitian kualitatif merupakan sebuah proses penelitian dengan menggunakan metode yang berbeda. Peneliti dalam hal ini akan menyusun, menganalisa kata kata, dan menghasilkan penelitian yang sesuai degan fakta dilapangan atau secara natural.

\section{Hasil dan Pembahasan}

Susilo Bambang Yudhoyono atau biasa dikenal masyarakat Indonesia sebagai SBY merupakan Presiden Indonesia yang ke 6 beliau merupakan presiden pertama yang dipilih melalui pemilihan langsung. Masa kepemimpinan 2 periode SBY berlangsung mulai dari tahun 2004 hingga 2014. Perjalanan karir perpolitikan SBY dimulai saat ia memutuskan untuk berhenti dari dunia kemiliterannya, meninggalkan jabatan-jabatan yang telah diraihnya dan mengambil pensiun dini pada tahun 2000. Setelah berhenti, ia kemudian aktif dalam perpolitikan dan menjadi Menteri Pertambangan dan Energi pada masa kepemimpinan Presiden Abdurrahman Wachid (Gus Dur). Tak lama dari pelantikannya, SBY kemudian diminta kembali oleh GusDur untuk menjabat sebagai Menteri Koordinator Politik, Sosial, dan Keamanan 
disingkat Menkopolsoskam. Kemudian, setelah masa kepemimpinan GusDur digantikan oleh Megawati Soekarno Putri, SBY kemudian di tunjuk kembali oleh sang presiden untuk menjabat sebagai Menkopolkam dalam kabinet gotong royong. Dan pada 11 Maret 2004, SBY memilih untuk mengundurkan diri sebagai Menteri kemudian memulai untuk mendirikan partainya sendiri yang kini dikenal sebagai partai Demokrat. Pada saat pemilihan umum pertama kali dilaksanakan, SBY menjabat dengan Jusuf Kalla sebagai wakilnya. Dan meraih suara sebanyak $60 \%$ dalam pemilu pertama tersebut.

Pada masa pemerintahannya selama 2 periode, Presiden SBY tentu merasakan betapa naik turunnya hubungan bilateral kedua negara ini. Hal tersebut tentu tidak terlepas dari pergantian kepemimpinan Perdana Menteri di Australia. Seperti pada masa kepemimpinan PM John Howard, Hubungan Australia dan Indonesia dirasa sangat menegang karena John Howard yang Anti Asia serta ditambah dengan adanya isu Timor Timur. Meskipun begitu, John Howard masih merasa perlu menjaga hubungan baik dengan negara tetangganya, Indonesia. Howard dalam Haryani manyatakan "Australia's bilateral relationship with Indonesia is a strategically important and very close one covering trade and investment, security, intelligence and police cooperation, education and extensive people-to people ties" (Haryani, 2008) John Howard masih melihat bahwa posisi Indonesia sangatlah penting bagi Australia. Selanjutnya pada masa kepemimpinan Kevin Rudd, hubungan Australia dan Indonesia kembali harmonis, hubungan PM Kevin Rudd dengan Presiden SBY sangatlah akrab bahkan SBY merupakan pemimpin negara pertama yang menghubungi Kevin Rudd saat dirinya terpilih menjadi Perdana Menteri Australia. Selain itu, Kevin Rudd dikabarkan sangat sering mengunjungi Indonesia dan melakukan banyak kerjasama dalam berbagai bidang dengan Indonesia. Dari sekian banyak penjelasan diatas, berikut kebijakan-kebijakan luar negeri Presiden SBY yang menandai naik turunnya hubungan Indonesia dengan Australia. Yaitu tentang kebijakan kerjasama kontra Terorisme, kebijakan terhadap penyadapan yang dilakukan oleh Australia, dan lain-lain. 


\section{Kerjasama yang menandai naik-turunnya hubungan Australia-Indonesia selama masa kepemimpinan SBY}

\section{Kerjasama Kontra Terorisme}

Pada masa ini (saat pemerintahan PM John Howard \& SBY) Orientasi kebijakan Luar Negeri Presiden SBY lebih menekankan pada upaya peningkatan kerjasama di bidang keamanan kawasan Australia-Indonesia. Karena sering terjadinya aksi-aksi terorisme yang menjadi penyebab utama kerjasama dalam bidang keamanan antara Australia dengan Indonesia ini dilakukan, pada 2002 terjadi aksi terorisme di salah satu klub bernama Paddy's Club di pulau Bali yang kemudian disebut sebagai peristiwa Bom Bali 1. Kasus terorisme lain juga terjadi pada September tahun 2004, aksi ini disebut sebagai bom Kuningan 2004. pengeboman ini terjadi di di depan kantor Kedutaan Besar Australia di Kuningan, Jakarta. Pada tahun berikutnya, tepatnya tanggal 1 Oktober 2005, aksi terorisme kembali muncul di Bali yang terjadi di Raja's Bar and Restaurant di Kuta Square, dan Kafe Nyoman, Kafe Menega Jimbaran, Bali. Aksi ini kemudian disebut sebagai aksi Bom Bali 2, Aksi-aksi tersebut menambah rentetan kasus terorisme yang terjadi pada masa pemerintahan Presiden SBY.

Kemudian muncul pertanyaan mengapa Australia membantu Indonesia dalam menangani aksi terorisme yang tidak terjadi dalam wilayah negara Australia sendiri? Pertanyaan tersebut dapat dijawab dengan fakta bahwa Australia dengan Indonesia merupakan negara yang sangat berdekatan, tidak menutup kemungkinan jika aksi tersebut bisa saja akan menyebar luas ke daratan Australia. Fakta yang kedua pada saat aksi Bom Bali 1, warga Australia menjadi korban dengan jumlah terbanyak yaitu sekitar 88 orang dari total 200 korban yang sedang berada di Bali pada saat itu (Setyawati \& Agussalim, 2015). Dari sini kemudian Australia melihat bahwa ancaman akan aksi terorisme sangat dekat dan perlu keseriusan dalam menangani masalah ini, terlebih lagi saat kantor Kedutaan Besar Indonesia menjadi sasaran terorisme. Sebagai bentuk keseriusannya Australia mengirimkan lebih dari 80 personel Australia Federal Police (AFP) guna untuk membantu kepolisian Indonesia dalam menangani kasus ini. 
Sebelumnya, Polisi Republik Indonesia (POLRI) memiliki Memorandum of Understanding (MoU) dengan beberapa negara salah satunya dengan Australia dalam hal ini adalah kepolisiannya (AFP) (Muhammad \& Sulistyo., 2006). Dan pengiriman AFP ini, dilakukan karena adanya MoU atau nota kesepakatan tersebut yang mengharuskan keduanya saling menjaga dan berkerjasama satu sama lain. Australia Federal Police (AFP) ini sangat berkontribusi dalam membantu kepolisian Indonesia menemukan pelaku dari aksi terorisme ini. AFP menyediakan dukungan berupa penyelidikan forensik dan membantu pembuatan sketsa pelaku Bom Bali. Dan dalam kurang dari satu bulan, penyidik telah mengidentifikasi tersangka yang dinilai berkaitan dengan aksi terorisme ini serta mulai mengungkap lingkaran kasus terorisme ini.

Selain itu, ada 2 poin utama untuk melihat kerjasama Australia dan Indonesia dalam hal terorisme pada masa kepemimpinan Presiden Susilo Bambang yudhoyono. Yaitu :

1. Demi keamanan kawasan Australia-Indonesia dan demi menjaga hubungan baik antara keduanya. Pada tahun 2005, Presiden SBY bersama dengan PM John Howard menandatangani Joint Declaration of Comprehensive Partnership Between Indonesia and Australia

2. Pada 13 November 2006, Menteri Luar Negeri RI Dr. N. Hassan Wirajuda dan Menteri Luar Negeri Australia, Alexander Downer menandatangani kerjasama dalam bidang keamanan di Lombok yang kemudian disebut dengan perjanjian Lombok atau Lombok Treaty. Lombok Treaty merupakan perjanjian yang mengatur kerangka kerjasama di bidang pertahanan, kontra terorisme, penegakan hukum, intelijen, keamanan maritim, keamanan pencegahan senjata pemusnah massal, keselamatan pembangunan dan kerjasama darurat, kerjasama organisasi dunia tentang isu-isu keamanan serta konsultasi permasalahan keamanan yang menjadi fokus utama kepentingan kedua negara, meskipun kerjasama ini bukan termasuk sebuah pakta militer, namun perjanjian ini mengatur kerjasama keamanan dalam cakupan yang sangat luas.(Kompas.com, 2008) 
Melalui kerjasama keamanan seperti yang telah dipaparkan sebelumnya, kedua negara akan sama-sama mendapatkan dampak positif dan juga akan mendapatkan keuntungan. Pada era saat ini, aksi-aksi terorisme tentu dapat menyebar ke seluruh penjuru dunia dengan mudahnya, didukung pula dengan perkembangan teknologi yang kian canggih. Terlebih lagi mengingat bahwa Australia merupakan negara yang sangat dekat secara geografis dengan Indonesia dan juga dinilai dekat dengan Amerika Serikat sebagai negara yang sangat anti mencanangkan War on Terror. Dengan adanya kerjasama-kerjasama seperti ini, Australia setidaknya akan mendapatkan jaminan keselamatan dari ancaman aksi terorisme. Dan untuk Indonesia, dari kerjasama ini tentu memberi dampak baik karena Australia memberikan bantuan dana untuk menangani terorisme sebesar 10 juta dollar Australia, dan juga pihak kepolisian Republik Indonesia dapat berbagi dan menambah pengetahuan dengan Australia Federal Police (AFP) khususnya dalam menangani kasus-kasus terorisme.

\section{Kasus Penyadapan}

Hubungan diplomatik antara Australia dan Indonesia semakin diperumit dengan adanya kasus penyadapan yang terjadi pada bulan Agustus tahun 2009. Penyadapan ini dilakukan oleh Defence Signal Directorate (DSD) yang juga merupakan intelejen Australia dan telah dilakukan kepada Presiden Indonesia saat itu yaitu Susilo Bambang Yudhoyono sebanyak 15 kali. Hal ini tentu saja membuat citra Indonesia terhadap Australia menjadi buruk karena Australia tidak bisa mengindahkan kedaulatan Indonesia dan tidak memiliki etika dalam bernegara. Sejak terbuktinya kasus ini, tentu hubungan antara Australia dan Indonesia mengalami ketegangan karena kedua negara ini dalam sejarahnya menjalin hubungan bilateral yang selalu naik turun. Kasus ini mulai ramai diperbincangkan semenjak mantan staf badan keamanan nasional NSA Amerika Serikat yang bernama Edward Snowden, membocorkan jaringan teknologi informasi Amerika Serikat yang digunakan oleh DSD Australia guna untuk menyadap negara-negara di Eropa dan beberapa negara Asia Tenggara salah satunya Indonesia. 
Dalam dokumen yang dipublikasikan oleh Australian Broadcasting Coorporation $(A B C)$ ada slide yang berjudul DSD Slide:IA Leadership Targets and Their Handsets menunjukan beberapa nama pejabat Indonesia yang telefon genggam nya telah tersadap. Daftar nama-nama tersebut adalah:

\begin{tabular}{|c|c|c|c|}
\hline $\mathrm{NO}$ & JABATAN & NAMA & JENIS HP\& SIGNAL \\
\hline 1. & Presiden Indonesia & $\begin{array}{ll}\text { Susilo } & \text { Bambang } \\
\text { Yudhoyono } & \end{array}$ & Nokia E90-1 \& sinyal 3G \\
\hline 2. & $\begin{array}{ll}\text { Ibu } & \text { Negara } \\
\text { Indonesia } & \\
\end{array}$ & Kristiani Herawati & Nokia E90-1 \& sinyal 3G \\
\hline 3. & $\begin{array}{ll}\text { Wakil } & \text { Presiden } \\
\text { Indonesia } & \\
\end{array}$ & Boediono & $\begin{array}{l}\text { BlackBerry Bold } 9000 \& \\
\text { sinyal 3G }\end{array}$ \\
\hline 4. & $\begin{array}{l}\text { Mantan Wakil } \\
\text { Presiden Indonesia }\end{array}$ & Jusuf Kalla & $\begin{array}{l}\begin{array}{l}\text { Samsung } \\
\text { sinyal 3G }\end{array} \\
\end{array}$ \\
\hline 5. & $\begin{array}{lr}\text { Juru } & \text { Bicara } \\
\text { Kepresidenan bidang } \\
\text { Luar Negeri }\end{array}$ & Dino Patti Djalal & $\begin{array}{l}\text { BlackBerry Bold } 9000 \& \\
\text { sinyal 3G }\end{array}$ \\
\hline 6. & $\begin{array}{l}\text { Juru Bicara } \\
\text { Kepresidenan }\end{array}$ & Andi Mallaranggeng & Nokia E71-1 \& sinyal 3G \\
\hline 7. & $\begin{array}{l}\text { Menteri Sekretaris } \\
\text { Negara }\end{array}$ & Hatta Rajasa & Nokia E90-1 \& sinyal 3G \\
\hline 8. & Menteri ekonomi & Sri Mulyani Indrawati & Nokia E90-1 \& sinyal 3G \\
\hline 9. & $\begin{array}{l}\text { Menteri Koor. } \\
\text { Politik Hukum dan } \\
\text { HAM }\end{array}$ & Widodo AS & Nokia E66-1 \& sinyal 3G \\
\hline 10. & $\begin{array}{ll}\text { Menteri } & \text { Negara } \\
\text { BUMN } & \end{array}$ & Sofyan Djalil & Nokia E90-1 \& sinyal 3G \\
\hline
\end{tabular}

Dalam slide DSD tersebut terdapat juga beberapa tulisan seperti "Top Secret Commint" yang berarti bahwa slide ini sangat rahasia. selain itu ada juga "reveal their secrets, protect our own" yang berarti ungkapkan rahasia mereka dan lindungi kita sendiri. dari hal ini bisa diketahui bahwa alasan utama Australia melakukan penyadapan terhadap Indonesia adalah untuk sebuah perlindungan. Meski begitu hal ini tentu sangat merugikan pihak Indonesia dan mengharuskan Indonesia segera mengambil tindakan untuk merespon hal ini yang mana tetap harus dipertimbangkan secara matang karena ini merupakan isu yang sangat 
sensitive bagi dua negara yang saling berdekatan dan memiliki riwayat hubungan bilateral. Untuk itu, SBY mengambil langkah-langkah berupa :

1. Pemanggilan Duta Besar Indonesia untuk Australia, Nadjib Riphat Kesoema di Canberra untuk segera kembali ke tanah air dan berkonsultasi bersama mengenai masalah ini. (Waluyo, 2013) dan tidak memungkinkan untuk bekerja dalam situasi genting seperti itu juga menjadi alasan lain pemanggilan Duta Besar.

2. SBY mengirimi surat kepada Australia untuk meminta penjelasan resmi atas sikap Australia terhadap pemerintah Indonesia (KOMINFO, 2013)

3. Indonesia kembali mereview kerjasama yang berkaitan dengan Australia, seperti menghentikan latihan gabungan antara TNI Angakatan Laut, Angkatan Darat, Angkatan Udara dengan Tentara Australia. Menunda kerjasama penukaran informasi dan intelejen dua negara. Serta menghentikan kerjasama dalam permasalahan bersama (people smuggling)

4. Merencanakan roadmap 6 langkah yang akan digunakan untuk memulihkan kembali hubungan bilateral kedua Negara pasca kasus penyadapan ini. pelaksanaan roadmap ini kemudian diawali dengan pertemuan utusan kedua negara yaitu Menteri Luar Negeri Indonesia Marty Natalegawa dan Menteri Luar Negeri Australia Julie Bishop. (Agus, 2013)

5. Membuat protokol code of conduct sebagai jaminan demi terbentuknya kembali kepercayaan Indonesia terhadap Australia, karena protokol ini akan bersifat mengikat, jelas, adil dan dipatuhi.

Meskipun memang pada awalnya PM Australia Tony Abbot dinilai enggan untuk meminta maaf terkait kasus penyadapan ini dengan pernyataannya "Australia should not be expected to apologize for the steps we take to protect our country now or in the past" namun, Tony Abbot tetap merespon surat yang dikirimkan oleh Presiden SBY, Adapun balasan respon dari Australia mengenai kasus penyadapan ini adalah dengan membalas surat yang dikirim oleh Indonesia (detikNews, 2013). Dalam surat balasan tersebut, Perdana Menteri Australia yang dijabat oleh Tony Abbot, pada tahun 2013 menjawab dalam 3 substansi yaitu: 
1. Australia berkeinginan untuk tetap melanjutkan hubungan yang lebih baik serta meneruskan kerjasama bilateral dengan Indonesia.

2. Australia menyatakan akan berkomitmen untuk menjaga hubungan bilateral dengan Indonesia dan tidak akan melakukan hal yang sekiranya akan merugikan Indonesia di masa yang akan datang.

3. Australia menyetujui usulan untuk me rebuilding trust serta kerjamasa bilateral kedua Negara dan menyetujui kode etik yang mengikat, jelas, adil dan dipatuhi. (detikNews, 2013)

Dalam perihal hubungan antar Negara, kasus penyadapan Australia terhadap Indonesia tentu merupakan hal yang tidak baik dilakukan oleh negara yang saling menjalin hubungan bilateral, terlebih Australia dan Indonesia merupakan negara tetangga yang saling berdekatan. Kasus penyadapan ini membuktikan bahwa Australia tidak menghormati kedaulatan NKRI sebagai negara terdekatnya. Namun kasus ini memang bukan dianggap sebagai kejahatan melainkan pelanggaran kode etik diplomatik antar Negara kasus ini juga lebih ditunjukan kepada sikap diplomatik serta pemaafan (Thontowi, 2015)

\section{Dukungan Australia terhadap gerakan separatisme Papua.}

Selain mendukung Timor Timur (pada masa kepemimpinan BJ Habibie), Australia juga ikut terlibat dalam masalah internal Indonesia seperti gerakan separatisme Papua. Hal-hal pendukung separatisme di Papua sebenarnya sudah ada sejak awal kemerdekaan saat pembagian wilayah Indonesia dan terus dicampuri oleh faktor internal maupun eksternal hingga sampai kepemimpinan Presiden SBY. Gerakan separatis Papua tertuang dalam sebuah Organisasi yang disebut OPM atau Organisasi Papua Merdeka. Beberapa negara juga dinilai menjadi pendukung gerakan ini salah satunya Australia. Pendanaan OPM pun dikabarkan bersumber dari Australia.

Dengan banyaknya SDM dan SDA di Papua, letak strategis Papua di kawasan pasifik serta perasaan di 'anak tiri'kan oleh Indonesia sebab sangat kurangnya pembangunan fasilitas disana kala itu tentu membuat Australia ingin memberikan bantuan penuhnya kepada Papua untuk kestabilan keamanan serta 
pertahanan jika Papua menjadi negara merdeka yang berada di dalam pengaruh Australia.

Sikap Australia lainnya yang dianggap sebagai dukungan atas separatisme Papua adalah pemberian visa kepada 42 WNI yang berasal dari Papua pada tahun 2006. hal ini tentu membuat Indonesia merasa bahwa Australia mendukung penuh agar Papua lebih berpihak kepada Australia dan Australia dianggap tidak menghormati kedaulatan Indonesia dengan selalu mencampuri urusan dalam Negeri, ditambah lagi dengan desas-desus separatisme yang belum menurun membuat Australia terlihat jelas sangat menginginkan Papua melepaskan diri dari Indonesia, meskipun Australia beralasan bahwa pemberian visa ini atas dasar kemanusiaan (detikNews, 2006)

Reaksi demi reaksi untuk merespon hal ini pun berdatangan baik dari Pemerintah maupun warga Negara Indonesia. Seperti pemulangan Duta besar Indonesia di Canberra sebagai tanda Indonesia tidak menyukai sikap Australia tersebut. Aksi unjuk rasa yang dilakukan organisasi FMPC-NKRI (Forum Masyarakat Papua Cinta NKRI) juga terjadi didepan kantor kedutaan besar Australia di Jakarta. Terlebih lagi,Indonesia segera melakukan antisipasi agar Australia tidak lebih jauh lagi mencampuri urusan Indonesia. Hal itu diatur dalam sebuah perjanjian Lombok Treaty pada tahun 2006. Selain membahas tentang keamanan, Lombok Treaty juga mengatur tentang separatisme Papua. Dan hal itu tertuang dalam prinsip "Pernyataan atas kedaulatan, Kesatuan, Kemerdekaan, dan Integritas Wilayah" yang juga bermakna penegasan bahwa Papua merupakan salah satu bagian dari Negara Kesatuan Republik Indonesia.

Berdasarkan temuan diatas, singkatnya dapat disimpulkan bahwa hubungan bilateral antara Australia dan Indonesia dimasa pemerintahan Presiden ke 6, Susilo Bambang Yudhoyono juga tetap mengalami kenaikan dan penurunan, sama seperti saat kepemimpinan Presiden-Presiden sebelumnya. Hal tersebut didasari oleh banyak faktor baik itu internal maupun eksternal, seperti pergantian kepemimpinan Perdana Menteri di Australia ( hubungan bilateral saat PM Kevin Rudd menjabat lebih meningkat dibandingkan hubungan saat John Howard 
menjabat PM Australia ), perbedaan partai darimana para Perdana Menteri berasal (John Howard sebagai PM Australia yang berasal dari partai liberal sangat condong kepada Amerika dan dikenal sebagai "Anti Asia" kebijakankebijakannya diketahui akan lebih menguntungkan Australia dibanding menguntungkan kedua belah pihak), faktor internal di Australia maupun Indonesia (seperti pada kasus terorisme yang terjadi berurutan di Indonesia, menjadikan hubungan Australia-Indonesia menjadi membaik karena kesadaran harusnya melakukan kerjasama melawan terorisme), pengaruh negara Super Power (ada sangkut paut hubungan Amerika Serikat dan Australia dalam kasus penyadapan Indonesia tahun 2009) dan tentu masih banyak faktor lainnya.

\section{Kesimpulan}

Hubungan Australia dan Indonesia dikenal sebagai hubungan yang aneh karena selain bisa mengalami kenaikan juga bisa mengalami penurunan. hubungan yang aneh tersebut juga terjadi pada masa kepemimpinan presiden SBY dilihat dari kebijakan-kebijakan Luar Negerinya selama periodesasinya. Indonesia selain menjadi negara tetangga juga merupakan mitra Australia dalam beberapa bidang kerjasama seperti militer, ekonomi, pendidikan, sosial budaya dan lain-lain, begitu pun sebaliknya. Kedua negara ini terkadang akan sangat kooperatif namun pada waktu lainnya bisa menjadi rival yang cukup menciptakan sensitifitas di antara keduanya. Berdasarkan penelitian, ada beberapa faktor yang mempengaruh hal ini, seperti pergantian kepemimpinan di Australia, kondisi politik internal di masingmasing negara, adanya pengaruh negara super power dalam hubungan Australia dan Indonesia.

Meskipun begitu, Dengan kekayaan negara, SDA dan kekuatan politisasinya, Australia dan Indonesia sama-sama merupakan negara yang cukup berpengaruh di kawasan pasifik. Sejauh ini, walaupun hubungan kedua negara terkadang berada di titik rendah, namun keduanya masih tetap menyadari bahwa mereka saling membutuhkan dan perlu saling berkooperatif demi terjaganya keamanan bersama di kawasan. 


\section{Referensi}

\section{Buku}

Ball, D., \& Wilson, H. (1991). Strange neighbours: the Australia-Indonesia relationship. Allen \& Unwin Australia.

Booth, K., \& Wheeler, N. J. (2007). The Security Dilemma: Fear, Cooperation and Trust in World Politics (first edit). Palgrave Macmillan.

Chauvel, R., \& Dkk. (2005). Hubungan Indonesia-Australia: Tantangan dan Kesempatan dalam Hubungan Politik Bilateral (M. Chusnul (Ed.); edisi pert). Granit.

Irsan, A. (2010). Peluang dan Tantangan Diplomasi Indonesia. Kelompok Penerbit Grafindo Khazanah Ilmu.

Moleong, L. (2007). Metodologi Penelitian Kualitatif. Remaja Karya.

Muhammad, F., \& Sulistyo., H. (2006). Bom Bali: Peristiwa dan Pengungkapan. (Cet. 2.). Pensil-324.

Shoelhi, M. (2011). DIPLOMASI: Praktik Komunikasi Internasional. Remaja Rosdakarya.

Singh, B. (2002). Defense Relations Between Australia and Indonesia InThe Post-Cold War Era. Greenwood Press.

Wheeler, N. J. (2018). Trusting Enemies: Interpersonal Relationship in International Conflict. Oxford University Press

\section{Jurnal Online}

Agus, R. (2013). Penyadapan Australia: Enam Langkah Penyelesaian Dimulai. Bisnis.com. Diperoleh dari https://kabar24.bisnis.com/read/20131204/15/190423/penyadapan-australiaenam-langkah-penyelesaian-dimulai

Burke, A. (2008). Fear of Security: Australia's Invasion Anxiety (Rev. ed). Port Melbourne, Vic.: Cambridge University Press. Diperoleh dari https://trove.nla.gov.au/work/8370418?q\&versionId=42651265 detikNews. (2006). Pemberian Visa Australia ke 42 Warga Papua Hal Manusiawi. Diperoleh dari https://news.detik.com/berita/d-567105/pemberian-visa-australia-ke-42-warga-papuahal-manusiawi

detikNews. (2013). Ini Isi Surat Balasan PM Tony Abbott Terhadap Surat Presiden SBY. sindonews. Diperoleh dari https://news.detik.com/berita/2424356/ini-isi-surat-balasan-pmtony-abbott-terhadap-surat-presiden-sby?991104topnews=

KOMINFO. (2013). Tunggu Jawaban Resmi, Indonesia Hentikan Kerjasama Intelijen dan Militer dengan Australia. Diperoleh dari https://kominfo.go.id/content/detail/3514/tunggujawaban-resmi-indonesia-hentikan-kerjasama-intelijen-dan-militer-dengan-australia/0/berita Kompas.com. (2008). Perjanjian Keamanan RI-Australia Resmi Berlaku. Diperoleh dari https://nasional.kompas.com/read/2008/02/07/16475529/perjanjian.keamanan.riaustralia.resmi.berlaku.

Setyawati, S. M., \& Agussalim, D. (2015). Security Complex Indonesia-Australia dan Pengaruhnya terhadap Dinamika Hubungan Kedua Negara. Jurnal Ilmu Sosial Dan Ilmu Politik, 19(2), 121. Diperoleh dari https://doi.org/10.22146/jsp.10848

Waluyo, A. (2013). Protes Penyadapan, Indonesia Tarik Dubes RI untuk Australia. VOA Indonesia. Diperoleh dari https://www.voaindonesia.com/a/indonesia-panggil-dubesaustralia-soal-dugaan-mata-mata/1792253.html

\section{Jurnal Offline}

Haryani, S. (2008). Counterterrorism cooperation between Indonesia and Australia: 


\section{Global Insigint Journal}

Vol 05, No. 02

April - September 2020

ISSN 2541-318X

Comparison Between The Reign Megawati Sukarnoputriand Susilo Bambang Yudhoyono. Journal Unair, 21, 352-360.

Prabaningtyas, R. F. (2013). Indonesia-Australia: Menguji Persahabatan di Tengah Konflik Penyadapan. 20(1).

Thontowi, J. (2015). Penyadapan dalam Hukum Internasional dan Implikasinya terhadap Hubungan Diplomatik Indonesia dengan Australia Jawahir Thontowi. 183-202. 